\title{
Effect of Biofertilizers and P-levels on Yield, Nutrient Content, Uptake and Physico-Chemical Properties of Soil under Blackgram (Vigna mungo L.)
}

\author{
Surya Kant ${ }^{1}$, Achin Kumar ${ }^{2}$, Satendra Kumar ${ }^{1}$, Vipin Kumar ${ }^{2}$ and O.P. Gurjar ${ }^{3}$ \\ ${ }^{1}$ Department of Soil Science Sardar Vallabhbhai Patel University of Agriculture and Technology, \\ Modipuram, Meerut- 250110 (U.P.), India \\ ${ }^{2}$ Department of Soil Science and Agricultural Chemistry, Institute of Agricultural Sciences \\ Banaras Hindu University, Varanasi-221005, (U.P.), India \\ ${ }^{3}$ Department of Soil and Water Conservation, RGSC, Barkachha, BHU \\ Mirzapur -231001, (U.P.), India \\ *Corresponding author
}

\section{A B S T R A C T}

Keywords

Biofertilizer, Yield, content, Physicochemical properties and Blackgram.

Article Info

Accepted:

20 February 2017

Available Online:

10 March 2017
A field experiment was conducted in kharif 2011on blackgram genotype T-9. The experiment was laid out in randomized block design with three replication and thirteen treatments. There was significant improvement recorded in yield, nutrient content, uptake and physico-chemical properties viz. $\mathrm{pH}$, electrical conductivity, organic carbon and available $\mathrm{N}$ and $\mathrm{P}$ of soil under black gram crop. Grain yield was increased by $47.06 \%$ in treatment $\mathrm{T}_{13}$ over control while, organic carbon showed significantly highly positive correlation with available nitrogen $(\mathrm{r}=.878)$ in post harvest soil. However, combination of rhizobium, PSB and P levels had proved significant influence on yield, content, uptake of nutrient and physico-chemical properties of soil under blackgram. Furthermore, inoculation of rhizobia and PSB into the soil found beneficial to increase the availability of native fixed phosphate and to reduce the use of fertilizers and build up significant improvement in residual soil fertility.

\section{Introduction}

Pulses are one of the important segments of Indian agriculture after cereals and oilseeds. India and central Asia are considered as the primary and the secondary centers of origin of black gram respectively. The distribution of black gram is comparatively restricted to tropical regions. The productivity of pulses is quite low since they are mainly cultivated in low fertile soil. Pulses are not only improving soil health by enriching nitrogen status, long term fertility but also sustainability of the cropping systems (Anonymous, 2011). The role of microorganisms in solubilizing inorganic phosphates in soil and making them available to plants is well known (Barroso et al., 2006). The nutritional requirement of pulses is similar to cereal but due to the unique feature of biological nitrogen fixation only $20 \mathrm{~kg} \mathrm{ha}^{-1}$ nitrogen is recommended. Rhizobium is the bacteria which are involve in symbiotic biological nitrogen fixation; success of biological nitrogen fixation depends on population of Rhizobia in soil. Rhizobium is widely distributed in soils of the tropics which have the ability to fix atmospheric nitrogen in symbiotic 
association. The amount of nitrogen fixed varies with the strain of Rhizobium, the plant species and environmental conditions. Rhizobium requires phosphorus for its growth and survival in soil, Rhizosphere colonization, infection and nodule development and energy transformation during Nitrogen fixation in root nodules (Hara et al., 1988).

Phosphorus is second most critical plant nutrient, but for pulses, it assumes primary importance, owing to its important role in root proliferation and thereby atmospheric nitrogen fixation. The yield and nutritional quality of pulses is greatly influenced by application of phosphorus.Phosphorous has referred to as the "Master key element" in crop production. Most of the phosphorous present in soil is unavailable to plants which are made available by action of efficient micro organism like bacteria, fungi, and even cyanobacteria.

These microorganisms bring about solubilization by the production of organic acid and phosphate enzyme activity. As regards phosphate only about 15-20 per cent of the applied phosphorous is utilized by first crop. The phosphate solubalising Bacteria (PSB), dissolving inter locked phosphates appear to have an important implication in Indian agriculture (Alikhani et al., 2006).

In particular, soil microorganisms are effective in releasing phosphate from total soil phosphorus through solubilization and mineralization. It is generally believed that a starter dose of phosphorus enhances the yield of crop. So the present experiment was conducted to find out the effect of Rhizobium, PSB inoculation and phosphorus levels on yield, concentration and uptake of nutrients by black gram and to manage soil phosphate is to optimize crop production and minimize phosphate loss from soils.

\section{Materials and Methods}

The field experiment was conducted in kharif season of 2011 at Crop Research Centre, Chirori of Sardar Vallabhbhai Patel University of Agriculture and Technology, Meerut (U.P.), India, to evaluate the effect of biofertilizers and P-levels on yield, nutrient content, uptake and physicoo-chemical properties of soil under blackgram (Vigna mungo L). The experiment was arranged in randomized block design with three replications, each plot size being $3.0 \mathrm{~m} \times 4.0 \mathrm{~m}$ (Table 1). Soil collected from research farm was analysed for various initial physicochemical properties given in parentheses, viz. bulk density $\left(1.38 \mathrm{~g} \mathrm{~cm}^{-3}\right)$, particle density (2.65 $\left.\mathrm{g} \mathrm{cm}^{-3}\right), \mathrm{pH}(8.2)$, EC $\left(0.28 \mathrm{dSm}^{-1}\right)$, organic carbon $(0.45 \%)$, porosity $(46.52 \%)$, available $\mathrm{N}\left(150.0 \mathrm{~kg} \mathrm{ha}^{-1}\right)$, available $\mathrm{P}(11.30$ $\left.\mathrm{kg} \mathrm{ha}^{-1}\right)$ and available $\mathrm{K}\left(170.0 \mathrm{~kg} \mathrm{ha}^{-1}\right)$ was analysed by standard procedure. Treatments consisted of 3 levels of phosphorus $(25,50$ and $75 \mathrm{~kg} \mathrm{ha}^{-1}$ ) and two carrier based cultures (Rhizobium and PSB). The cultures (Rhizobium and PSB) was mixed in minimum amount of water and Gur solution. The seeds of black gram were mixed up in various Rhizobium cultures and kept under shade before sowing the seeds. All the treatments comprising of different levels of $\mathrm{P}$ @ 25, 50 and $75 \mathrm{~kg} \mathrm{ha}^{-1}$ respectively, were applied as basal as per treatment description through Single super phosphate. Intercultural operations viz., weeding, irrigation, and insecticide spray were done as and when required. The yield, nutrient content and uptake and physico-chemical properties were recorded at pertinent stages. All obtained data from experiment were statistically analyzed by analysis of variance (ANOVA) according to randomized block design as prescribed by (Panse and Sukhatme, 1978). Standard error of mean in each case and critical difference only for significance cases were computed at $5 \%$ levels of probability. 


\section{Results and Discussion}

\section{Yield}

Grain yield was significantly affected by different treatments (Table 2). The maximum grain yield $\left(9.28 \mathrm{q} \mathrm{ha}^{-1}\right)$ was recorded in treatment $\mathrm{T}_{13}\left(75 \mathrm{~kg} \mathrm{P}_{2} \mathrm{O}_{5} \mathrm{ha}^{-1}+\mathrm{PSB}+\right.$ Rhizobium) respectively, which were superior to rest of the treatments, while minimum was recorded in $\mathrm{T}_{1}$ (control). Grain yield was increased by $47.06 \%$ in treatment $\mathrm{T}_{13}$ over control.

Straw yield was significantly affected by different treatments (Table 2). The maximum grain yield $\left(31.60 \mathrm{q} \mathrm{ha}^{-1}\right)$ was recorded in treatment $\mathrm{T}_{13}\left(75 \mathrm{~kg} \mathrm{P}_{2} \mathrm{O}_{5} \mathrm{ha}^{-1}+\mathrm{PSB}+\right.$ Rhizobium) respectively, which were superior to rest of the treatments, while minimum was recorded in $\mathrm{T}_{1}$ (control). Straw yield was increased by $47.11 \%$ in treatment $\mathrm{T}_{13}$ over control.

Biological yield was significantly affected by different treatments (Table 2). The maximum grain yield (40.88 $\left.\mathrm{q} \mathrm{ha}^{-1}\right)$ was recorded in treatment $\mathrm{T}_{13}\left(75 \mathrm{~kg} \mathrm{P}_{2} \mathrm{O}_{5} \mathrm{ha}^{-1}+\mathrm{PSB}+\right.$ Rhizobium) respectively, which were superior to rest of the treatments, while minimum was recorded in $T_{1}$ (control). Straw yield was increased by $47.10 \%$ in treatment $\mathrm{T}_{13}$ over control.

Harvest index was significantly affected by different treatments and it is varied from 21.87 to $23.16 \%$ (Table 2). The maximum HI $(23.16 \%)$ was recorded in treatment $\mathrm{T}_{11}(75$ $\left.\mathrm{kg} \mathrm{P}_{2} \mathrm{O}_{5} \mathrm{ha}^{-1}+\mathrm{PSB}\right)$ respectively, which were superior to rest of the treatments.

The grain and biological yield ( $\mathrm{q} \mathrm{ha}^{-1}$ ) increased significantly, when inoculation was supplemented with phosphorus due to the synergistic effect of Rhizobium and PSB inoculation over control. Highly significant increase was observed in combined application of $\mathrm{Co}$ - inoculation of Rhizobium, PSB and $75 \mathrm{~kg} \mathrm{P}_{2} \mathrm{O}_{5} \mathrm{ha}^{-1}$. $\mathrm{T}_{13}$ treatment was found superior than others. The similar findings were also obtained by Singh et al., (1993). The result is supported by Jain et al., (1999), Meena et al., (2002), Tanwar et al (2002), Bhat et al., (2005), Band et al., (2007) and Rathore et al., (2007). The optimum level of phosphorous application, thus lead to better development of grain yield.

\section{Nutrients content and uptake}

\section{$\mathbf{N}$ and $\mathbf{P}$ content in grain and straw}

The nitrogen content in grain and straw was affected by different treatments has been presented in table 3. It is apparent from that result the application of Rhizobium, PSB and P-levels on significantly affected the content of nitrogen in grain and straw. Nitrogen content of grain varied from 3.30 to $3.83 \%$ and in straw varied from 1.20 to $1.80 \%$ under different treatments. The maximum $\mathrm{N}$ content in grain $(3.83 \%)$ and in straw $(1.80 \%)$ was found in $\mathrm{T}_{13}\left(75 \mathrm{~kg} \mathrm{P}_{2} \mathrm{O}_{5} \mathrm{ha}^{-1}+\mathrm{PSB}+\right.$ Rhizobium) which statistically at par to $\mathrm{T}_{6}(25$ $\mathrm{kg}_{2} \mathrm{O}_{5} \mathrm{ha}^{-1}+$ Rhizobium $), \mathrm{T}_{7}\left(25 \mathrm{~kg} \mathrm{P}_{2} \mathrm{O}_{5} \mathrm{ha}^{-}\right.$ ${ }^{1}+\mathrm{PSB}+$ Rhizobium $), \mathrm{T}_{9}\left(50 \mathrm{~kg} \mathrm{P}_{2} \mathrm{O}_{5} \mathrm{ha}^{-1}+\right.$ Rhizobium), $\mathrm{T}_{10}\left(50 \mathrm{~kg} \mathrm{P}_{2} \mathrm{O}_{5} \mathrm{ha}^{-1}+\mathrm{PSB}+\right.$ Rhizobium) and $\mathrm{T}_{12}\left(75 \mathrm{~kg} \mathrm{P}_{2} \mathrm{O}_{5} \mathrm{ha}^{-1}+\right.$ Rhizobium). $\mathrm{T}_{13}\left(75 \mathrm{~kg} \mathrm{P}_{2} \mathrm{O}_{5}+\mathrm{PSB}+\right.$ Rhizobium) was significantly superior to rest of the treatments, while minimum $\mathrm{N}$ content in grain $(3.30 \%)$ and in wheat $(1.20 \%)$ was recorded in $\mathrm{T}_{1}$ control Most of the treatments related to nitrogen content in Straw were found statistically at par. Similar result was also reported by Tanwar et al., (2003).

The phosphorus content in grain and straw was affected by different treatments has been presented in table 3. It is apparent from that result the application of Rhizobium, PSB and P-levels on significantly affected the content 
of nitrogen in grain and straw. Phosphorus content of grain varied from 0.21 to $0.36 \%$ and in straw varied from 0.10 to $0.20 \%$ under different treatments. The maximum $\mathrm{P}$ content in grain $(0.36 \%)$ and in straw $(0.20 \%)$ was found in $\mathrm{T}_{13} \quad\left(\mathrm{~kg} \mathrm{P}_{2} \mathrm{O}_{5} \mathrm{ha}^{-1}+\mathrm{PSB}+\right.$ Rhizobium) which were statistically at par to $\mathrm{T}_{11}\left(75 \mathrm{~kg} \mathrm{P}_{2} \mathrm{O}_{5} \mathrm{ha}^{-1}+\mathrm{PSB}\right)$ and significantly superior to rest of the treatments. Most of the treatments related to phosphorus content in Straw were found statistically at par.

Higher NP content of plant parts in these treatments can be related to the better plant growth and sufficient nutrient supply in these treatments. Better root growth with proper nutrient supply may the reason for extraction of available plant nutrient from soil depth and ultimately which improve the nutrient content in plant parts. The positive effect inoculation on $\mathrm{N}$ and $\mathrm{P}$ content of black gram was also reported by Singh et al., (2009) and Jain et al., (2003).

\section{$\mathrm{N}$ and $\mathrm{P}$ uptake by grain and straw}

The nitrogen uptake in grain and straw was affected by different treatments has been presented in table 3. It is apparent from that result the application of Rhizobium, PSB and P-levels on significantly affected the uptake of nitrogen in grain and straw. Nitrogen uptake of grain varied from 20.83 to $35.55 \mathrm{~kg}$ $\mathrm{ha}^{-1}$ and in straw varied from 25.78 to 56.88 $\mathrm{kg} \mathrm{ha}{ }^{-1}$ under different treatments. The maximum $\mathrm{N}$ uptake in grain $\left(35.55 \mathrm{~kg} \mathrm{ha}^{-1}\right)$ and in straw (56.88 kg ha $\mathrm{kas}^{-1}$ ) wound in $\mathrm{T}_{13}$ $\left(75 \mathrm{~kg} \mathrm{P}_{2} \mathrm{O}_{5} \mathrm{ha}^{-1}+\mathrm{PSB}+\right.$ Rhizobium $)$ which was significantly superior to rest of the treatments, while minimum $\mathrm{N}$ uptake in grain $\left(20.83 \mathrm{~kg} \mathrm{ha}^{-1}\right)$ and in straw $\left(25.78 \mathrm{~kg} \mathrm{ha}^{-1}\right)$ was recorded in $\mathrm{T}_{1}$ control.

The phosphorus uptake in grain and straw was affected by different treatments has been presented in table 3. It is apparent from that result the application of Rhizobium, PSB and
P-levels on significantly affected the uptake of nitrogen in grain and straw. Phosphorus uptake of grain varied from 1.33 to $3.34 \mathrm{~kg}$ $\mathrm{ha}^{-1}$ and in straw varied from 2.15 to $6.32 \mathrm{~kg}$ $\mathrm{ha}^{-1}$ under different treatments. The maximum $\mathrm{P}$ uptake in grain $\left(3.34 \mathrm{~kg} \mathrm{ha}^{-1}\right)$ and in straw $\left(6.32 \mathrm{~kg} \mathrm{ha}^{-1}\right)$ was found in $\mathrm{T}_{13}\left(\mathrm{~kg} \mathrm{P}_{2} \mathrm{O}_{5} \mathrm{ha}^{-1}\right.$ $+\mathrm{PSB}+$ Rhizobium) which were statistically at par to $\mathrm{T}_{11}\left(75 \mathrm{~kg} \mathrm{P}_{2} \mathrm{O}_{5} \mathrm{ha}^{-1}+\mathrm{PSB}\right)$ and significantly superior to rest of the treatments. Similar result reported by Jain et al., (2003) also reported that uptake of $\mathrm{N}$ and $\mathrm{P}$ increased significantly due to inoculation. Summauria et al., (2009) also reported the positive effect of inoculation on $\mathrm{N}$ and $\mathrm{P}$ uptake by legume. Singh et al., (2009) also reported that uptake of $\mathrm{P}$ increased significantly due to inoculation.

\section{Physico-chemical properties of post harvest soil}

pH: The effect of different treatments on soil $\mathrm{pH}$ was found non-significant, it is presented in table 4. $\mathrm{pH}$ was ranged from 7.28 to 8.15. No particular trend was found in soil under different treatments,

Electrical conductivity: The effect of different treatments on soil EC was also found non-significant, it is presented in table 4. EC was ranged from 0.14 to $0.25 \mathrm{dsm}^{-1}$. The EC was slightly higher in the treatments receiving PSB application.

Organic carbon: The effect of different treatments on soil organic carbon (\%) was found significant, it was also found that soil Organic carbon ranged from 0.24 to $0.50 \%$, is presented in table 4. Organic carbon content in soil improved slightly due to integration of nutrient sources. As the production of total biomass was higher in these treatments, more amount of residue might have added in the soil in form of leave fall and roots which will build up the organic matter level in soil. 
Similar result was also reported by Rajkhowa (2003) and Mohan et al., (2007). These results also corroborate with the findings of Sharma et al., (2005), Sharma et al., (2005, Baskar (2003) and Tolanur and Badanur (2003).

Available N: The available nitrogen status of soil was significantly affected by different treatments presented in table 4 . The values of available nitrogen content for $\mathrm{T}_{1}, \mathrm{~T}_{2}, \mathrm{~T}_{3}, \mathrm{~T}_{4}$, $\mathrm{T}_{5}, \mathrm{~T}_{6}, \mathrm{~T}_{7}, \mathrm{~T}_{8}, \mathrm{~T}_{9}, \mathrm{~T}_{10}, \mathrm{~T}_{11}, \mathrm{~T}_{12}$ and $\mathrm{T}_{13}$ treatments were $160.12,161.58,184.16$, $188.41, \quad 169.44, \quad 195.0, \quad 198.21, \quad 176.87$, $200.21,201.10,182.91,203.70$ and $205.70 \mathrm{~kg}$ $\mathrm{ha}^{-1}$ at harvesting, respectively. Available soil nitrogen varied from 160.12 to $205.70 \mathrm{~kg} \mathrm{ha}^{-1}$ highest being in $\mathrm{T}_{13}$ and lowest in $\mathrm{T}_{1}$. Sharma et al., (2009) noticed that enhancement in available $\mathrm{N}$ content of soil with the balanced use of nutrient sources.

Available P: The available phosphorus status of soil was significantly affected by different treatments presented in table 4 . The values of available phosphorus content for $\mathrm{T}_{1}, \mathrm{~T}_{2}, \mathrm{~T}_{3}$, $\mathrm{T}_{4}, \mathrm{~T}_{5}, \mathrm{~T}_{6}, \mathrm{~T}_{7}, \mathrm{~T}_{8}, \mathrm{~T}_{9}, \mathrm{~T}_{10}, \mathrm{~T}_{11}, \mathrm{~T}_{12}$ and $\mathrm{T}_{13}$ treatments were $8.50,10.60,10.21,11.35$, $12.36,11.40,12.40,12.54,12.30,12.50$, $13.60,13.31$ and $15.60 \mathrm{~kg} \mathrm{ha}^{-1}$ at harvesting, respectively. Available soil phosphorus varied from 8.50 to $15.60 \mathrm{~kg} \mathrm{ha}^{-1}$ highest being in $\mathrm{T}_{13}$ and lowest in $\mathrm{T}_{1}$. Similar results were obtained by Kumar et al., (2003) and Jamir et al., (2013) have also noted the improvement in available phosphorus status due to balanced use of chemical fertilizers.

Correlation matrix between physicochemical properties of post harvest soil samples

$\mathrm{pH}$ and EC significantly negetive correlated with organic carbon, available nitrogen and phsphorus. Organic carbon showed significantly correlated with available nitrogen $(\mathrm{r}=.878)$ and phosphorus $(\mathrm{r}=.851)$ in a posative way but available nitrogen also showed a posative correlation with available phosphorus in table 5 .

Table.1 Details of the field experiment and treatment

\begin{tabular}{|c|c|c|}
\hline \multicolumn{3}{|l|}{ Experimental details } \\
\hline Crop & \multicolumn{2}{|c|}{ Blackgram (Vigina mungo L.) Cv T-9 } \\
\hline Experimental design & \multicolumn{2}{|c|}{ Randomized Block Design (RBD) } \\
\hline Number of treatments & \multicolumn{2}{|l|}{13} \\
\hline Number of replication & \multicolumn{2}{|l|}{3} \\
\hline $\begin{array}{l}\text { Number of plots } \\
\text { Treatment }\end{array}$ & \multicolumn{2}{|c|}{$\begin{array}{l}39 \quad(13 \times 3) \\
\mathrm{P}-25,50 \text { and } 75 \mathrm{~kg} \mathrm{ha}^{-1}, \text { Rhizobium and PSB }\end{array}$} \\
\hline $\begin{array}{c}\text { Treatments details : } \\
\mathrm{T}_{1} \text { (Uninoculated, } \\
\mathrm{T}_{3} \text { (Rhizobium), } \\
\mathrm{T}_{5}\left(25 \mathrm{~kg} \mathrm{ha}^{-1} \mathrm{P}_{2} \mathrm{O}_{5+}\right. \\
\mathrm{T}_{7}\left(25 \mathrm{~kg} \mathrm{ha}^{-1} \mathrm{P}_{2} \mathrm{O}_{5+}\right. \\
\mathrm{T}_{9}\left(50 \mathrm{~kg} \mathrm{ha}^{-1} \mathrm{P}_{2} \mathrm{O}_{5}\right. \\
\mathrm{T}_{11}\left(75 \mathrm{~kg} \mathrm{ha}^{-1} \mathrm{P}_{2} \mathrm{O}_{5}\right. \\
\mathrm{T}_{13}\left(75 \mathrm{~kg} \mathrm{ha}^{-1} \mathrm{P}_{2} \mathrm{O}_{5}\right.\end{array}$ & $\begin{array}{l}\text { B), } \\
\text { B + Rhizobium), } \\
\text { hizobium), } \\
\text { SB), } \\
\text { SB+Rhizobium) }\end{array}$ & $\begin{array}{l}\mathrm{T}_{2}(\mathrm{PSB}), \\
\mathrm{T}_{4}(\mathrm{PSB}+\text { Rhizobium }), \\
\mathrm{T}_{6}\left(25 \mathrm{~kg} \mathrm{ha}^{-1} \mathrm{P}_{2} \mathrm{O}_{5} \text { Rhizobium }\right), \\
\mathrm{T}_{8}\left(50 \mathrm{~kg} \mathrm{ha}^{-1} \mathrm{P}_{2} \mathrm{O}_{5}+\mathrm{PSB}\right), \\
\mathrm{T}_{10}\left(50 \mathrm{~kg} \mathrm{ha}^{-1} \mathrm{P}_{2} \mathrm{O}_{5}+\mathrm{PSB}+\text { Rhizobium }\right), \\
\mathrm{T}_{12}\left(75 \mathrm{~kg} \mathrm{ha}^{-1} \mathrm{P}_{2} \mathrm{O}_{5}+\text { Rhizobium }\right)\end{array}$ \\
\hline
\end{tabular}

$\mathrm{PSB}=$ Phosphate Solubilizing Bacteria 
Table.2 Effect of Rhizobium, PSB and P-levels on grain, straw, biological yield and harvest index of blackgram

\begin{tabular}{|c|c|c|c|c|}
\hline Treatments & Grain yield $\left(\mathrm{q} \mathrm{ha}^{-1}\right)$ & Straw yield $\left(q h^{-1}\right)$ & Biological yield $\left(\mathrm{q} \mathrm{ha}^{-1}\right)$ & Harvest Index (\%) \\
\hline $\mathrm{T} 1$ & 6.31 & 21.48 & 27.79 & 22.71 \\
\hline $\mathbf{T 2}$ & 6.91 & 23.27 & 30.18 & 22.90 \\
\hline T3 & 7.05 & 24.27 & 31.81 & 22.16 \\
\hline $\mathbf{T 4}$ & 7.33 & 25.10 & 32.43 & 22.60 \\
\hline T5 & 6.92 & 24.77 & 31.19 & 22.19 \\
\hline T6 & 7.41 & 26.47 & 33.88 & 21.87 \\
\hline $\mathbf{T 7}$ & 8.02 & 27.07 & 35.09 & 22.86 \\
\hline $\mathbf{T 8}$ & 7.50 & 26.77 & 34.26 & 21.89 \\
\hline T9 & 8.08 & 28.70 & 36.78 & 21.97 \\
\hline T10 & 9.15 & 31.47 & 40.62 & 22.52 \\
\hline T11 & 8.86 & 29.40 & 38.26 & 23.16 \\
\hline T12 & 9.03 & 30.33 & 39.36 & 22.94 \\
\hline T13 & 9.28 & 31.60 & 40.88 & 22.70 \\
\hline SEm \pm & 0.25 & 0.34 & 0.34 & .036 \\
\hline $\mathrm{CD}(\mathbf{P}=\mathbf{0 . 0 5})$ & 0.74 & 1.01 & 0.99 & 0.106 \\
\hline
\end{tabular}

Table.3 Effect of Rhizobium, PSB and P-levels on N and P content (\%) and uptake (kg ha $\left.{ }^{-1}\right)$ by grain and straw of blackgram

\begin{tabular}{|c|c|c|c|c|c|c|c|c|}
\hline \multirow[t]{2}{*}{ Treatments } & \multicolumn{2}{|c|}{$\mathrm{N}$ content $(\%)$} & \multicolumn{2}{|c|}{ N uptake $\left(\mathrm{kg} \mathrm{ha}^{-1)}\right.$} & \multicolumn{2}{|c|}{$P$ content $(\%)$} & \multicolumn{2}{|c|}{ P uptake $\left(\mathrm{kg} \mathrm{ha}^{-1}\right)$} \\
\hline & Grain & Straw & Grain & Straw & Grain & Straw & Grain & Straw \\
\hline T1 & 3.30 & 1.20 & 20.83 & 25.78 & 0.21 & 0.10 & 1.33 & 2.15 \\
\hline T2 & 3.34 & 1.24 & 23.07 & 28.85 & 0.23 & 0.12 & 1.59 & 2.79 \\
\hline T3 & 3.50 & 1.30 & 24.69 & 31.55 & 0.22 & 0.14 & 1.55 & 3.40 \\
\hline T4 & 3.60 & 1.38 & 26.41 & 34.65 & 0.24 & 0.13 & 1.76 & 3.26 \\
\hline T5 & 3.36 & 1.26 & 23.25 & 31.21 & 0.26 & 0.15 & 1.80 & 3.72 \\
\hline T6 & 3.65 & 1.42 & 27.04 & 37.59 & 0.23 & 0.12 & 1.71 & 3.18 \\
\hline $\mathbf{T} 7$ & 3.75 & 1.48 & 30.08 & 40.08 & 0.27 & 0.16 & 2.16 & 4.33 \\
\hline T8 & 3.40 & 1.27 & 25.49 & 34.00 & 0.30 & 0.17 & 2.25 & 4.55 \\
\hline T9 & 3.69 & 1.45 & 29.82 & 41.62 & 0.25 & 0.13 & 2.02 & 3.73 \\
\hline T10 & 3.80 & 1.70 & 34.78 & 53.51 & 0.32 & 0.18 & 2.94 & 5.66 \\
\hline T11 & 3.46 & 1.29 & 30.68 & 37.93 & 0.35 & 0.18 & 3.10 & 5.30 \\
\hline T12 & 3.72 & 1.68 & 33.55 & 50.95 & 0.28 & 0.14 & 2.53 & 4.25 \\
\hline T13 & 3.83 & 1.80 & 35.55 & 56.88 & 0.36 & 0.20 & 3.34 & 6.32 \\
\hline SEm \pm & 0.08 & 0.10 & 0.39 & 0.44 & 0.01 & 0.01 & 0.09 & 0.23 \\
\hline $\mathrm{CD}(\mathrm{P}=\mathbf{0 . 0 5})$ & 0.24 & 0.29 & 1.14 & 1.28 & 0.03 & 0.03 & 0.25 & 0.66 \\
\hline
\end{tabular}


Table.4 Effect of Rhizobium, PSB and P-levels on physico-chemical properties of post harvest soil samples under blackgram

\begin{tabular}{|c|c|c|c|c|c|}
\hline Treatments & Soil pH & $\mathrm{EC}\left(\mathrm{dsm}^{-1}\right)$ & Organic Carbon \% & Available Nitrogen $\left(\mathrm{kg} \mathrm{ha}^{-1}\right)$ & Available Phosphorus (kg ha $\left.{ }^{-1}\right)$ \\
\hline $\mathbf{T}_{1}$ & 8.15 & 0.25 & 0.24 & 160.12 & 8.50 \\
\hline $\mathbf{T}_{2}$ & 7.95 & 0.24 & 0.28 & 161.58 & 10.60 \\
\hline $\mathbf{T}_{3}$ & 8.05 & 0.22 & 0.37 & 184.16 & 10.21 \\
\hline $\mathbf{T}_{4}$ & 7.81 & 0.21 & $\mathbf{0 . 3 9}$ & 188.41 & 11.35 \\
\hline $\mathbf{T}_{5}$ & 7.99 & 0.18 & 0.36 & 169.44 & 12.36 \\
\hline $\mathbf{T}_{6}$ & 8.02 & 0.17 & 0.42 & 195.00 & 11.40 \\
\hline $\mathbf{T}_{7}$ & 7.83 & 0.19 & 0.45 & 198.21 & 12.40 \\
\hline $\mathbf{T}_{8}$ & 7.28 & 0.16 & 0.44 & 176.87 & 12.54 \\
\hline $\mathbf{T}_{9}$ & 8.09 & 0.17 & 0.46 & 200.21 & 12.30 \\
\hline $\mathbf{T}_{10}$ & 7.36 & 0.15 & 0.49 & 201.10 & 12.50 \\
\hline $\mathbf{T}_{11}$ & 7.93 & 0.20 & 0.47 & 182.91 & 13.60 \\
\hline $\mathbf{T}_{12}$ & 8.06 & 0.17 & 0.48 & 203.70 & 13.31 \\
\hline $\mathbf{T}_{13}$ & 7.53 & 0.14 & 0.50 & 205.70 & 15.60 \\
\hline S Em \pm & 0.83 & 0.02 & 0.02 & 2.44 & 0.41 \\
\hline $\mathrm{CD}(\mathrm{P}=\mathbf{0 . 0 5})$ & N.S. & N.S. & 0.06 & 7.18 & 1.20 \\
\hline
\end{tabular}

Table.5 Correlation matrix between post harvest soil parameters

\begin{tabular}{|c|c|c|c|c|c|}
\hline Parametars & pH & EC & Organic Carbon & Available $\mathbf{N}$ & Available $\mathbf{P}$ \\
\hline pH & 1 & & & & \\
\hline EC & $.589 *$ & 1 & & & \\
\hline Organic Carbon & -.476 & $-.864 * *$ & 1 & & \\
\hline Available N & -.248 & $-.742 * *$ & $.878 * *$ & 1 & \\
\hline Available $\mathbf{P}$ & -.475 & $-.806 * *$ & $.851 * *$ & $.653 *$ & 1 \\
\hline
\end{tabular}

*. Correlation is significant at the 0.05 level (2-tailed).

**. Correlation is significant at the 0.01 level (2-tailed). 
Organic carbon showed significantly highly posative correlation with available nitrogen $(\mathrm{r}=.878)$. In conclusion, from the above study it is concluded that the combination of Rhizobium, PSB and P levels were found superior than alone application of treatments in terms of yield, nutrient concentration, uptake and physico-chemical parameters viz. $\mathrm{pH}$, EC, organic carbon, available $\mathrm{N}$, and available $\mathrm{P}$ of soil under Blackgram. Grain yield increased by $47.06 \%$ due to application of Rhizobium and PSB along with $75 \mathrm{~kg} \mathrm{ha}^{-1}$ $\mathrm{P}_{2} \mathrm{O}_{5}$ in treatment $\mathrm{T}_{13}$ gave the maximum grain yield (9.28 $\mathrm{q} \mathrm{ha}^{-1}$ ) respectively, which were superior to rest of the treatments, while minimum was recorded in $\mathrm{T}_{1}$ (control). Inoculation of rhizobia and PSB into the soil found beneficial to increase the availability of native fixed phosphate and to reduce the use of fertilizers and build up significant improvement in residual soil fertility.

\section{References}

Alikhani, H.A., Saleh, R.N. and Antoun, H. 2006. Phosphate solubilisation activity of rhizobia native to Iranian soils. Plant Soil, 287: 35-41.

Anonymous. 2011. Agricultural statistics at glance, Ministry of agriculture, Government of India.

Band, A.M., Mendhe, S.N., Kolte, H.S., Choudhary, R.L., Verma, R. and Sharma, S.K. 2007. Nutrient management studies in French bean (Phaseolus vulgaris L.). J. Soils and Crops, 17(2): 367-372.

Barroso, C.V., Pereira, G.T. and Nahas, E. 2006. Solubilization of CaHPO4 and AlPO4 by Aspergillus niger in culture media with different carbon and nitrogen sources. Braz. J. Microbiol., 37: 434-438.

Baskar, K. 2003. Effect of integrated use of inorganic fertilizer and FYM or green leaf manure on uptake and nutrient use efficiency of rice-rice system on an
Inceptisol. J. Indian Society of Soil Sci., 51: 47-51.

Bhat, S.A., Thenua, O.V.S., Shivakumar, B.G. and Malik, J.K. 2005. Performance of summer greengram [Vigna radiata (L.)] as influenced by biofertilizers and phosphorus nutrition. Haryana J. Agron., 21(2): 203-205.

Jain, L.K. and Singh, Pushpendra. 2003. Growth and nutrient uptake of chickpea (Cicer arietinum L.) as influenced by bio-fertilizers and phosphorus nutrition. Crop Res. Hisar, 25(3): 410-413.

Jain, P.C., Kushwaha, P.S., Dhakad, U.S., Khan, H. and Trivedi, S.K. 1999. Response of chickpea (Cicer arietinum L.) to phosphorus and Biofertilizer. Legume Res., 22(4): 241-244.

Jamir, S., Singh, V.B., Kanaujia, S.P. and Singh, A.K. 2013. Effect of integrated nutrient management on growth, yield and quality of onion (Allium cepa L.). Progressive Horticulture, 45(2): 373-380.

Kumar, M., Singh, R.P. and Rana, N.S. 2003. Effect of organic source of nutrition on productivity of rice. Indian J. Agron., 48(9): 175-177.

Meena, Raj pal, Jat, N.L. and Meena, N.L. 2002. Effect of phosphorus and biofertilizers (Rhizobium and PSB) on yield and yield attributes of cluster bean [Cyamopsis tetragonoloba (L.) Taub]. Annals of Agri. Res., 23(2): 349-351.

Mohan, S.C. and chandragiri, K.K. 2007. Nutrient uptake and post harvest available soil nutrient under organic farming system in cotton + black gram inter cropping system. Int. J. Plant Sci., Muzaffarnagar, 2(1): 120-123.

O' Hara, G.W., Bookerd, N. and Dilworth, M.J. 1988. Mineral constraints to nitrogen fixation, PI. Soil, 198: 93-110.

Panse, V.G. and Sukhatme, P.V. 1978. Statistical methods for agricultural 
workers. ICAR, New Delhi..

Rajkhowa, D.J., Saikia, M. and Rajkhowa, K.M. 2003. Effect of vermicompost and levels of fertilizers on green gram. Legume Res., 26(1): 63-65.

Rathore, V.S., Singh, J.P., Soni, M.L. and Beniwal, R.K. 2007. Effect of nutrient management on growth, productivity and nutrient uptake of rainfed clusterbean (Cyamopsis tetragonoloba) in arid region. Indian J. Agri. Sci., 77(6): 349-353.

Sammauria, R., Yadav, R.S. and Nagar, K.C. 2009. Performance of cluster bean (Cyamopsis tetragonoloba) as influenced by nitrogen and phosphorus fertilization and biofertilizers in Western Rajasthan. Indian J. Agron., 54(3): 319-323.

Sharma, R.P., Datt, N. and Chander, G. 2009. Effect of vermicompost, FYM, and chemical fertilizers on yield and nutrient uptake and soil fertility in okraonion sequence in wet temperate zone of Himachal Pradesh. J. Indian Society of Soil Sci., 57(3): 357-361.

Sharma, R.P., Sharma, A. and Sharma, J.K. 2005. Productivity, nutrient uptake, soil fertility and economics as affected by chemical fertilizers and FYM in broccoli (Brassica oleracea var italica) in an entisol. Indian J. Agri. Sci., 75: 576-579.
Sharma, S., Dubey, Y.P., Kaistha, B.P. and Verma, T.S. 2005. Effect of Rhizobium inoculation and phosphorus level on symbiotic parameters, growth and yield of French bean (Phaseolus vulgaris L.) in north-western acid alfisol. Legume Res., 28: 103-106.

Singh, A.K., Choudhary, R.K. and Sharma, R.P. 1993. Effect of inoculation and fertilizer levels on yield, yield attributes and nutrient uptake of greengram (Phaseolus radiatus) and blackgram (P. mungo). Ind. J. Agron., 38: 663-665.

Singh, R.P. Kumar, O.N. Singh, Yogeshwar, Dwivedi, Sachchidanand and Singh, J.P. 2009. Effect of integrated nutrient management on growth, yield, nutrient uptake and ecnomics of french bean (Phaseolus vulgaris). Indian J. Agri. Sci., 79(2): 122-128.

Tanwar, S.P.S., Sharma, G.L. and Chahar, M.S. 2002. Effects of phosphorus and biofertilizers on the growth and productivity of black gram. Annals of Agri. Res., 23(3): 491-493.

Tolanur, Badanur, V.P. 2003. Changes in organic carbon, available $\mathrm{N}, \mathrm{P}$ and $\mathrm{K}$ under integrated use of organic manure, green manure and fertilizer on sustaining productivity of pearl milletpigeon pea system and fertility of an Inceptisol. J. Indian society of soil Sci., 51: $37-41$.

\section{How to cite this article:}

Surya Kant, Achin Kumar, Satendra Kumar, Vipin Kumar and Gurjar, O.P. 2017. Effect of Biofertilizers and P-levels on Yield, Nutrient Content, Uptake and Physico-Chemical Properties of Soil under Blackgram (Vigna mungo L.). Int.J.Curr.Microbiol.App.Sci. 6(3): 1243-1251. doi: https://doi.org/10.20546/ijcmas.2017.603.143 